\title{
ESCRITA E FORMACCÃO DOCENTE: DESAFIOS NA PRÁTICA DE ESCRITA NA FORMAÇÃO INICIAL PARA A DOCÊNCIA EM LÍNGUA PORTUGUESA
}

\author{
WRITING AND TEACHING EDUCATION: CHALLENGES IN WRITING \\ PRACTICE IN INITIAL TRAINING FOR TEACHING IN PORTUGUESE
}

\author{
Tânia Guedes Magalhães ${ }^{1}$ \\ Andreia Rezende Garcia Reis ${ }^{2}$
}

\begin{abstract}
RESUMO: Este trabalho apresenta o resultado de uma pesquisa empreendida com alunos do curso de Letras/Português da Universidade Federal de Juiz de Fora (MG) que buscou analisar a compreensăo dos alunos sobre a escrita de gêneros acadêmicos em disciplinas de estágio supervisionado em Língua Portuguesa, realizada no último ano do curso integral, em 2014. Consideramos que a inserçáo do aluno em práticas de escrita de gêneros acadêmicos é um importante processo de socializaçăo. Como metodologia, utilizamos questionário aberto, aplicado ao final do período em que os alunos produziram seus textos, após escrita-reescrita-reflexâo sobre a escrita. Os dados mostram que a) uma minoria discente está imersa em práticas de escrita acadêmica ao longo do curso de Letras; b) os alunos deparam-se ao final do curso com dificuldades de escrita ainda nâo detectadas ao longo da graduaçấo; c) há maior envolvimento dos alunos na escrita de artigos e relatos quando há contexto de circulaçăo.
\end{abstract}

PALAVRAS-CHAVE: Formaçăo de professores; Gêneros textuais; Escrita.

ABSTRACT: This work shows the result of a research with Portuguese Language students of Federal University of Juiz de Fora (MG) that analysed their understanding about academic genres written in supervised internship of Portuguese Language in last period of full time course in 2014. We understand that the student's insertion in written practices of academic genres is an important socialization process. Methodologically, we used open questionnaire applied at the end of the period when the students wrote their texts, after writing - rewriting - reflection about written. The data show us that a) a minority of students is immersed in academic written practice during the Portuguese Language undergraduation; b) the students face up difficulties in writing not detected along the course; c) there is more student's engagement in the written of paper and reports in circulation context.

KEYWORDS: Teacher Training; Text Genres; Writting.

\footnotetext{
$1 \quad$ Graduada em Letras (UFJF) e Doutora em Estudos Linguísticos (UFF). Professora dos cursos de Letras e Pedagogia da UFJF e professora do Programa de Pós-Graduaçăo em Educaçâo - Linha Linguagem, conhecimento e formaçẫo de professores. E-mail: tania.magalhaes95@gmail.com

2 Graduada em Letras (UFJF) e Doutora em Linguística (UFRJ). Professora dos cursos de Letras e Pedagogia da UFJF. E-mail: andreiargarcia@yahoo.com.br
} 


\section{INTRODUÇÃO}

As práticas de escrita na universidade têm sido foco de estudos e pesquisas recentes, em funçâo da problemática que o tema gera. De acordo com Ferrarezi (2014), recorrentemente tratamos de problemas de escrita de alunos do ensino básico, mas no curso superior as dificuldades de escrita săo também constantes. Práticas de letramento acadêmico têm sido bastante investigadas por diferentes autores e com diferentes orientaçôes teóricas (FIAD, SILVA, 2009; STREET, 2010; BEZERRA, 2012; MARINHO, 2010; CRISTÓVÂO, BORK, VIEIRA, 2015; MENDES, SILVA, GONÇALVES e MELO, 2015), uma vez que a inserçăo de um novo perfil de aluno no ensino superior e as demandas cada vez mais crescentes de publicaçōes têm permitido reflexóes e pesquisas sobre o assunto. Tais reflexóes săo necessárias na medida em que temos visto a entrada de alunos no curso superior sem superar questóes básicas de escrita (RINCK, BOCH, ASSIS, 2015).

Este artigo contribui com reflexôes já empreendidas por diferentes pesquisadores, enfocando uma pesquisa realizada com alunos do curso de licenciatura em Letras-Português da Universidade Federal de Juiz de Fora (MG), realizada no último ano do curso ( $7^{\circ}$ e $8^{\circ}$ períodos) após a escrita dos gêneros artigo científico e relato de experiência, ${ }^{3}$ durante as disciplinas de Reflexóes sobre a atuaçâo no espaço escolar (RAEE) I e II, que acompanha as atividades realizadas nos Estágios Supervisionados I e II (obrigatórios), ministradas no $2^{\circ}$ semestre de 2014. Partindo da impressâo de que os alunos do curso de Letras estavam imersos em amplas e diversificadas práticas de escrita acadêmica sistematizadas, objetivamos, nesta pesquisa, analisar a compreensăo dos discentes sobre a prática de produçăo de artigo e relato de experiência como trabalhos finais da disciplina RAEE I e II e Estágio Supervisionado I e II, bem como as dificuldades encontradas nessa escrita, com o intuito de, futuramente, realizar novas propostas e mudanças na formaçăo inicial de professores.

Em nossas investigaçôes, temos refletido sobre as mudanças nas práticas de escrita realizadas nas disciplinas teóricas cursadas concomitantemente aos estágios obrigatórios do curso. Ao longo de muitos anos, anteriormente a 2011, a escrita de relatórios foi a atividade central de análise e reflexăo sobre o estágio; no ano de 2013, realizamos atividades de escrita de artigos, para refletir sobre a o exercício profissional do professor que supervisiona o estágio na escola básica, cuja prática é observada anteriormente à docência, e relatos de experiência, para que o graduando analise sua própria atuaçăo. Tais mudanças visaram possibilitar uma prática de escrita de gêneros reconhecidos e que circulam no espaço acadêmico mais amplo, com uma maior visibilidade da escrita dos alunos, uma vez que artigos e relatos săo gêneros que podem ser encaminhados a periódicos e a eventos acadêmicos, ao contrário dos relatórios, em nossa instituiçấo.

Com base nessas primeiras observaçôes, apresentamos os fundamentos que embasaram nossa pesquisa, a escrita como prática social e a importância dos gêneros no aprendizado da escrita; em seguida, na metodologia, trazemos aspectos específicos do caso tratado, o curso de Letras da UFJF, para, entâo, apresentar a seçáo de dados, coletados por questionários aplicados a alunos do curso. Nesta seçăo, apresentamos

Artigo científico e relato de experiência serâo apresentados na seçăo seguinte. 
as reflexóes feitas pelos próprios discentes a partir das cinco questóes, separadas em blocos temáticos. Por fim, tecemos algumas consideraçóes relevantes apontadas pela prática vivenciada e pela pesquisa realizada.

Tais reflexôes têm contribuído para aperfeiçoar as escolhas metodológicas de nossas disciplinas e a qualidade da formaçăo inicial de professores desta universidade. Esperamos, com este trabalho, perceber melhor de que modo temos enfocado a escrita na formaçáo inicial docente, com vistas a propor, em futuras pesquisas, um alargamento de tais práticas que visam ao desenvolvimento da escrita docente, de modo mais coerente com a "unidade teoria-prática" sustentada por uma concepçáo discursiva de escrita, que passamos a apresentar.

\section{ESCRITA COMO PRÁTICA SOCIAL}

Considerar as práticas de escrita como uma prática social permite-nos, professores formadores e também em formaçâo, propor atividades aos alunos, num contexto de formaçăo inicial, que estejam pautadas numa concepçăo de linguagem sociointeracionista (BRONCKART, 2006) e sociocognitiva (BAGNO, 2014). A linguagem é social porque intervém nas interaçōes comunicativas, nos possibilita interagir com outros membros da nossa sociedade e porque toda açấo humana é, por si só, social; portanto, ser humano é ser na linguagem e é ser social (BAGNO, 2014).

Nâo somos meramente usuários da linguagem e da língua, pois produzimos discursos, refazemos discursos e ressignificamos os discursos alheios para construir os nossos, considerados como açôes de linguagem em contextos específicos, ou seja, açōes humanas e linguageiras ao mesmo tempo (BRONCKART, 2006).

É a partir de tais concepçôes que sustentamos e defendemos práticas de escrita na academia que sejam mais contextualizadas, em que os alunos possam "ser na linguagem" (BAGNO, 2014) e pela linguagem, em que possam construir seus discursos náo copiando e repetindo os discursos de teóricos e estudiosos lidos ou estudados, mas dialogando com eles, com suas teorias e perspectivas. Propomos interaçóes entre professor formador e alunos em formaçăo em constante troca de impressōes, compreensôes, saberes e experiências, a partir dos quais efetivamos o diálogo na formaçâo inicial, seja ele por meio da oralidade ou da escrita.

Ao esperarmos uma atitude de produtor de discursos vinda dos alunos em formaçâo, recém-chegados à universidade, nâo podemos esperar que eles já saibam pensar e agir por meio da escrita nesse espaço, uma vez que os usos que fazemos da escrita na academia sâo usos muito específicos, portanto, novos para esses alunos. Reconhecemos que tais alunos já transitam em diversos letramentos, săo falantes e escritores em língua materna, mas o conhecimento que possuem da escrita muitas vezes nâo lhes é suficiente para adequarem seus discursos escritos às expectativas dos professores e de outros interlocutores presentes no ambiente acadêmico. Nesse sentido, é preciso compreendermos que a aprendizagem da escrita năo se encontra concluída quando os alunos ingressam na universidade e que a formaçăo desses estudantes deve possibilitar uma formaçăo na e pela escrita (RINCK, BOCH, ASSIS, 2015). O fato de já terem concluído o ensino fundamental e médio náo significa que os universitários tenham conquistado capacidades de escrita que lhes deem condiçôes para elaboraçăo de 
gêneros acadêmicos, como resumos, resenhas, artigos, relatos e relatórios, por exemplo. A verdadeira inserçáo neste novo espaço de formaçăo, bem como o comportamento social que terăo nele, depende da participaçăo e da prática discursiva construída, sem a qual nâo terăo condiçóes efetivas de ingresso.

Para Marinho (2010), ao adotar pressupostos bakthinianos, as práticas de escrita universitária precisam ser incluídas nos currículos dos cursos de formaçăo, uma vez que somente a experiência de leitura e escrita - atividades de linguagem complementares - de gêneros acadêmicos poderá contribuir para uma interaçâo verbal bem sucedida entre alunos em formaçăo universitária e professores formadores. Defendemos que a aprendizagem da escrita acadêmica năo é, portanto, automática; mais do que isso, năo é porque sabemos escrever determinados gêneros que temos a capacidade de "dizer" por escrito ao elaborarmos textos que circularăo no ambiente universitário.

Ao elaborarmos nossos textos, lançamos măo de recursos linguísticos (lexicais e sintáticos, por exemplo) e de recursos da ordem das açôes de linguagem, ou seja, dos modelos de organizaçâo textual disponíveis em nossa língua e em nossa cultura. Por isso a importância dos gêneros para o Interacionismo Sociodiscursivo, que săo as diferentes "espécies de textos que podem ser produzidos pelos membros de uma comunidade verbal" (BRONCKART, 2010, p. 168). A produçâo de textos pertencentes a um ou outro gênero de texto está relacionada às condiçôes sociais pertinentes a determinado uso, condiçóes essas que nos levam a escolhas muito dependentes do contexto, ou seja, já estabilizadas pelo uso.

Ao ingressar para a universidade, os alunos desconhecem as atividades de linguagem próprias desse espaço institucionalizado e produtor de discursos. Eles vâo, aos poucos, conhecendo sua organizaçăo, seu funcionamento e as atividades de linguagem mais comuns que nele acontecem, como seminários, palestras, conferências, aulas de diferentes tipos, colóquios, mesas-redondas etc. Em cada uma dessas atividades de linguagem, sâo produzidos variados gêneros, verdadeiras açōes de linguagem, pelos sujeitos, a partir das representaçōes linguísticas e sociais construídas (BRONCKART, 2006). À medida que passam a conviver nesse novo espaço, a compartilhar dos discursos nele produzidos e a ter experiências de leitura, escuta, produçâo oral e escrita com os gêneros acadêmicos, os estudantes passam a conhecer as açôes que sâo praticadas pelos sujeitos ali presentes, seus interlocutores mais imediatos. Será somente a partir das experiências acadêmicas que os estudantes terâo condiçôes de produzir seus textos acadêmicos, que sâo os textos empíricos, materializados, pertencentes a determinado gênero, a serem lidos e reconhecidos pela comunidade como elementos pertinentes àquela atividade social e linguageira.

Essa concepçâo revela a importância e o valor da experiência com os textos, em práticas de leitura, escuta, produçăo oral e escrita, e, consequentemente, a qualidade da formaçăo de um estudante que se envolve com tais experiências ao longo de sua permanência na academia. O sucesso na formaçâo está diretamente ligado à prática de escrita constante, uma vez que ela é onipresente na universidade.

Um aspecto fundamental para o aperfeiçoamento da prática de escrita pelos alunos universitários sâo a postura e a mediaçăo dos professores, em orientaçôes detalhadas para a realizaçăo das tarefas, na leitura atenta dos textos escritos pelos 
alunos, no encaminhamento para reescrita, no convite à reflexăo sobre os textos ou trechos elaborados, enfim, numa série de condutas que văo refletir positivamente na qualidade das produçóes. O planejamento, a escrita e a reescrita de textos săo etapas constitutivas de qualquer escrita e, também, da escrita dos textos acadêmicos. Em pesquisa sobre a elaboraçăo de relatórios de estágio supervisionado no curso de Letras, Mendes, Silva, Gonçalves e Melo (2015) defendem a intervençăo do professor formador como essencial para reflexôes sobre os textos elaborados pelos alunos graduandos, na medida em que estes poderâo levá-las em consideraçáo para o processo de revisáo e reescrita, etapas importantes da prática autoral. Nesse sentido, as atividades de produçáo tornam-se também momentos profícuos para novas aprendizagens linguísticas, mediadas pelo professor.

Acreditamos que a interaçáo dos alunos em eventos de letramento acadêmico (STREET, 2010) contribuirá sobremaneira no percurso da graduaçâo e também na vida profissional futura dos estudantes, sobretudo dos do curso de Letras - Português, sujeitos da pesquisa a ser relatada em seçâo seguinte, uma vez que o modo como o professor de Língua Portuguesa compreende e encaminha as atividades de escrita na escola básica depende muito de suas experiências com a escrita no interior do curso de formaçâo inicial.

Compreender o texto como um processo infindável (MENDES, SILVA, GONÇALVES e MELO, 2015) e a escrita como um processo de autoria, e ao mesmo tempo de adequaçâo às situaçôes sócio-comunicativas, é de fundamental importância para o trabalho com a escrita no ensino fundamental, médio e superior, possíveis locais de trabalho dos graduandos em Letras. Assim, no curso de graduaçâo, o aluno precisa vivenciar experiências de escrita que o levem a considerá-las a partir de tais pressupostos. Acreditamos ser indispensável năo apenas abordar esses pressupostos em disciplinas teóricas, mas internalizá-la como experiência própria, de modo que isso se replique em sua prática futura.

De acordo com Bronckart (2015), as ciências da educaçăo trouxeram grandes contribuiçôes para a redefiniçâo das finalidades do ensino da língua materna em países francófonos, com base e em diálogo com as pesquisas de linguistas e psicólogos, na busca de definir objetivos práticos para esse ensino. Nas palavras do autor, essa finalidade seria: "deixar os alunos aptos a produzir e compreender os textos em uso em sua vida escolar e social e conceber um ensino gramatical que constituiria um verdadeiro apoio técnico a esse objetivo central" (BRONCKART, 2015, p. 32, grifo nosso). Essa perspectiva assumida pelo autor também se encontra presente em documentos nacionais que visam orientar as práticas de ensino da Língua Portuguesa, como os Parâmetros Curriculares Nacionais (BRASIL, 1997, 1998), por exemplo. Tal perspectiva também parece figurar no novo documento, a Base Nacional Comum Curricular, sobretudo na disciplina de Língua Portuguesa.

Se um dos objetivos é a produçâo de textos constitutivos da variedade textual que circula na sociedade, esse se torna um conteúdo com o qual os professores de Língua Portuguesa precisarăo trabalhar ao longo de sua trajetória profissional e, com isso, um conteúdo a ser estudado ao longo da formaçăo inicial. Isso se torna um problema a ser enfrentado justamente porque, segundo Gatti (2010, p. 1368), "os conteúdos específicos das disciplinas a serem ministradas em sala de aula năo săo objeto dos cursos de 
formaçăo inicial do professor." A grande parte da carga horária dos cursos de licenciatura está dedicada aos conhecimentos específicos da área de conhecimento e uma pequena parte às discussóes sobre a docência e aos conhecimentos teórico-metodológicos que serâo necessários à atuaçăo profissional do professor.

Atentas ao cenário descrito e preocupadas com a formaçăo do professor de Língua Portuguesa egresso do curso de Letras da Universidade Federal de Juiz de Fora, nós, professoras responsáveis pelo Estágio Supervisionado e pela disciplina de Reflexóes sobre a Atuaçáo no Espaço Escolar, que acompanha os estágios, buscamos propor e mediar atividades de produçấo escrita dos alunos com a possibilidade de dar voz ao futuro professor. Como menciona Andrade (2011), trata-se de implementar a interlocuçâo entre professor formador e professor em formaçăo, uma vez que formar passa a ser ensinar o estudante a falar e a usar a própria voz, em sentido metafórico.

Segundo Andrade (2011, p. 91), "A prática da teoria consiste na didática da formaçáo", ou seja, a didática e os encaminhamentos do professor formador, tanto num contexto de formaçâo continuada quanto inicial, precisam pautar-se em vivências da teoria, em situaçôes práticas que dialoguem e coloquem os estudantes em contato mais intenso com a teoria. É nessa perspectiva que concebemos as práticas de escrita na academia. Amparadas pelo Interacionismo Sociodiscursivo, buscamos orientar práticas de produçăo escrita mais autorais - nas quais os estudantes tenham o que dizer sobre sua experiência docente - e também concebidas como açōes de linguagem contextualizadas e com possibilidade de circulaçăo real - em atividades de linguagem acadêmicas ou em espaços de divulgaçăo de textos acadêmicos. Assim, a formaçâo dos futuros professores de Língua Portuguesa, profissionais da escrita por excelência, pauta-se em uma formaçăo pela escrita e para a escrita, como já salientamos.

Quando a escrita tem fins sociocomunicativos, com possibilidade de circulaçăo e interlocutores reais no contexto acadêmico, os alunos encaram a atividade com maior empolgaçâo, dedicam-se e adquirem mais autonomia ao longo do processo e depois da tarefa concluída. Possibilitar que a produçấo do texto escrito pelos estudantes faça parte de um evento de letramento acadêmico contribuirá significativamente para a formaçăo acadêmica dos estudantes e também para sua atuaçăo profissional posterior, como agentes de letramento e como incentivadores e mediadores efetivos do trabalho linguístico de seus futuros alunos.

Enfatizamos neste trabalho a escrita do artigo científico ${ }^{4}$ na formaçăo inicial do professor, considerando seu aprendizado fundamental por se tratar de uma escrita que exige trabalho aprofundado de compreensăo e análise. Para Mota-Roth (2010), o artigo acadêmico tem o objetivo de disseminar o resultado de pesquisa desenvolvida sobre um tema específico. Para sua escrita, o aluno precisa fazer extensas leituras de fundamentaçăo, desenvolver argumentaçăo, comparaçăo e sínteses analíticas entre diferentes correntes teóricas e abordagens de diversos autores, estabelecer objetivos, conhecer e discorrer sobre metodologia de pesquisa, manipular dados, realizar descriçâo e análise crítica de dados, bem como construir um resumo das principais

Consideramos "artigo" neste trabalho os textos que comunicam um resultado de pesquisa ou veiculam uma revisấo, conforme ABNT (NBR 6022, 2003). Mota-Roth (2010) usa a terminologia artigo acadêmico. 
conclusóes a que a pesquisa relatada no artigo se referiu. No caso de nossa realidade na UFJF, consideramos que, ao se inserir em turmas de Ensino Fundamental ou Médio para realizar a observaçâo da sala de aula para posterior atuaçâo docente, o aluno coleta dados e gera conhecimento novo a partir dessa reflexăo produzida na disciplina RAEE I e II, por nós ministrada. Nesse sentido, tal texto deve circular, lançando novas explanaçôes e ideias sobre a realidade escolar.

Já no tocante ao relato de experiência, trata-se de um gênero conhecido e comum na vida profissional do professor, sendo requerido e aceito em revistas e eventos acadêmicos. É um gênero que tem o objetivo de relatar o desenvolvimento de uma experiência, năo necessitando, por exemplo, como no artigo, de análise de dados mais acurada, já que o foco está na descriçăo das açôes realizadas. Tem fundamentaçăo teórica, bem como uma apresentaçăo do contexto em que a açáo foi desenvolvida. Na avaliaçăo dos resultados, năo se presume categorias rígidas, nem mesmo quantificaçâo, mas uma apreciaçăo dos ganhos obtidos com a vivência, as possíveis mudanças ocorridas pelo experimento. Assim como no artigo, o relato de experiência também prevê leitura e análise de obras de referência, mas o foco parece estar açâo e no afastamento que o aluno produz da própria prática, podendo, ao descrevê-la, analisá-la mais minuciosamente. É comum, em nossa disciplina, ouvirmos dos alunos que "depois que colocamos no papel, vemos o tanto de coisas que fizemos", confirmando que essa escrita proporciona visualizar e sistematizar mais claramente as próprias açóes pedagógicas. Acreditamos que o relato de experiência dá abertura maior à subjetividade do que o relatório de estágio, que é um texto mais técnico e objetivo.

Com base nesses pressupostos, nossas pesquisas têm se destinado a analisar quais textos os alunos têm produzido na graduaçấo, de que forma poderíamos deslocar e ressignificar a relaçâo teoria-prática na formaçăo inicial, perpassando a escrita nessa relaçăo, pesquisas essas que consideram também as avaliaçōes e reflexóes que os alunos, imersos nessas atividades, fazem sobre a própria escrita, que passamos, entấo, na seçăo seguinte, a descrever, apresentando questôes relativas à metodologia de trabalho, bem como análise de dados.

\section{METODOLOGIA E CONTEXTUALIZAÇÃO DA COLETA DE DADOS}

A pesquisa foi desenvolvida com alunos que cursavam o $7^{\circ}$ e $8^{\circ}$ períodos do curso de Letras - Português/Integral da UFJF no segundo semestre do ano de 2014. Tradicionalmente, o trabalho da disciplina de estágio do curso de Letras/Português era um relatório de estágio supervisionado, realizado no $8^{\circ}$ período, na antiga disciplina Didática do Português que era realizada juntamente à Prática de Ensino de LP. Entretanto, passamos a repensar essa prática por considerar que o relatório náo circulava publicamente para além de nossas disciplinas, o que poderia acontecer se eles fossem transformados em artigos e relatos para publicaçáo ou apresentaçăo em eventos. Ou se trabalhássemos tais gêneros em nossas atividades.

A partir do ano de 2011, com a reformulaçâo do curso, os alunos passaram a realizar a disciplina Reflexôes sobre a atuaçâo no espaço escolar I (RAEE I) no $7^{\circ}$ período, juntamente com o Estágio Supervisionado em LP I, e Reflexōes sobre atuaçāo no espaço escolar II (REAA II) no $8^{\circ}$ período, juntamente com o Estágio Supervisionado 
em LP II. As disciplinas de RAEE I e II săo denominadas "teóricas" e săo realizadas por professores universitários na Faculdade de Educaçáo, com formaçăo em Letras, em que săo discutidas teorias e práticas pedagógicas relativas ao ensino de LP, dando continuidade e principalmente aprofundamento aos conhecimentos das disciplinas Saberes Escolares de LP e Metodologia do Ensino de LP, realizadas no $3^{\circ}$ e $4^{\circ}$ períodos. Assim, o curso de Letras, ${ }^{5}$ hoje, na UFJF, apresenta a seguinte organizaçăo no que tange aos conteúdos destinados à reflexâo e atuaçâo sobre o ensino de Língua Portuguesa:

\section{Quadro 1: LICENCIATURA EM LETRAS/PORTUGUÊS E LITERATURAS - TURNO INTEGRAL (UFJF)}

\begin{tabular}{|c|c|c|c|}
\hline Período & $\begin{array}{c}\text { Disciplinas de Linguística e } \\
\text { Literaturas }\end{array}$ & $\begin{array}{c}\text { Tronco das disciplinas } \\
\text { pedagógicas de formação em } \\
\text { LP }\end{array}$ & Disciplinas obrigatórias \\
\hline $1^{\circ}$ & \multirow{8}{*}{$\begin{array}{l}\text { Disciplinas obrigatórias, eletivas } \\
\text { e oficinas referentes à formação } \\
\text { Letras - Português: Estudos } \\
\text { Linguísticos e Literários e } \\
\text { Línguas estrangeiras }\end{array}$} & & \\
\hline $2^{\circ}$ & & & \\
\hline $3^{\circ}$ & & $\begin{array}{l}\text { Saberes escolares de LP (60h) } \\
\text { com Prática escolar (30h) }\end{array}$ & \\
\hline $4^{\circ}$ & & $\begin{array}{c}\text { Metodologia do Ensino de LP } \\
(60 \mathrm{~h})\end{array}$ & $\begin{array}{c}\text { Processos de ensino - } \\
\text { aprendizagem }\end{array}$ \\
\hline $5^{\circ}$ & & & $\begin{array}{l}\text { Polít. Públic. e Gestão do Espaço } \\
\text { Escolar }\end{array}$ \\
\hline $6^{\circ}$ & & & Estado Sociedade e Educação \\
\hline $7^{\circ}$ & & Reflexões + Estágio I - 200h & Questões Filosóficas e Educação \\
\hline $8^{\circ}$ & & Reflexões + Estágio II - 200h & \\
\hline
\end{tabular}

Fonte: elaborado pelas autoras ${ }^{6}$

Nosso foco recaiu sobre os períodos destacados acima, em que atuamos como professoras das disciplinas RAEE I + Estágio I e RAEE II + Estágio II, que săo feitos em dois períodos subsequentes, por obrigatoriedade do curso. Os alunos realizam o estágio em escolas públicas e particulares da cidade de Juiz de Fora, conveniadas com a UFJF, bem como de cidades vizinhas à nossa, quando lá săo residentes.

Nessas disciplinas, realizamos atividades que envolveram, naquele período, os seguintes gêneros:

Quadro 2: Gêneros textuais abordados nas disciplinas RAEE I e II (2014)

\begin{tabular}{c|c}
\hline $7^{\circ}$ período (200h) & $8^{\circ}$ período (200h) \\
\hline RAEE I + Estágio I & RAEE II + Estágio II \\
\hline Plano de intervenção & Plano de intervenção \\
\hline Seminário de avaliação de aulas ministradas & Seminário de avaliação de aulas ministradas \\
\hline Relato de experiência & Relato de experiência \\
\hline Artigo científico & Artigo científico \\
\hline
\end{tabular}

Fonte: elaborado pelas autoras

5 Dados retirados de http://www.uff.br/faclet/graduacao/licenciaturas-em-letras/integral/portugues-erespectivas-literaturas/ Último acesso em junho de 2016.

6 http://www.ufjf.br/faclet/graduacao/licenciaturas-em-letras/integral/portugues-e-respectivasliteraturas/ 
Aplicamos um questionário em duas turmas de Letras/Português, composto por 5 questôes, sendo 4 abertas e uma fechada. Os questionários foram aplicados em duas turmas com uma média de 40 alunos, sendo que 15 de cada sala (totalizando 30) responderam e devolveram em aula logo após responderem. O questionário foi aplicado ao final da disciplina, quando o semestre já estava se finalizando, e quando as atividades já haviam terminado. Como professoras das disciplinas de RAEE I e II e Estágio I e II, respondemos a questionamentos e dúvidas no momento de responderem ao questionário. Somente o preencheram os alunos presentes, ou seja, náo foi possível levar para colegas ausentes, responder e entregar em aulas seguintes ou enviar por e-mail.

\section{OS DADOS}

Mais do que realizar trabalhos de escrita que ficassem circunscritos às disciplinas, nosso objetivo era que houvesse um profundo estudo da açâo de linguagem dos gêneros em questăo, bem como sua circulaçấo; ${ }^{7}$ por isso, ao longo do semestre, orientamos os alunos à escrita do artigo e do relato da seguinte forma:

\section{Quadro 3 - Atividades de escrita de artigo e relato de experiência nas disciplinas de RAEE I e II (2014) $8,9,10,11$}

\begin{tabular}{|c|c|}
\hline 1 & $\begin{array}{c}\text { Leitura de artigos científicos e relatos de experiências com base em análise de gêneros oriundos de } \\
\text { experiências realizadas em estágios de outras universidades }{ }^{8} \text { e em textos de alunos de outros períodos do } \\
\text { curso de Letras }\end{array}$ \\
\hline 2 & $\begin{array}{l}\text { Elaboração conjunta de um esboço/seções internas do } \text { artigo }^{9} \text { e do relato, }{ }^{10} \text { adaptado para as turmas em } \\
\text { questão e considerando a realidade das aulas e escolas observadas no estágio do curso de Letras da UFJF }\end{array}$ \\
\hline 3 & Elaboração da versão 1 do artigo e do relato \\
\hline 4 & $\begin{array}{l}\text { Apresentação da correção dessas primeiras versões comentadas aos alunos (com orientação extra para } \\
\text { alunos com dificuldades ou para alunos que deveriam fazer a reescrita total do artigo e do relato) }\end{array}$ \\
\hline 5 & Reescrita individual dos alunos - Elaboração da versão 2 dos dois gêneros \\
\hline 6 & Entrega da versão definitiva (duas semanas depois) e nova correção \\
\hline 7 & $\begin{array}{c}\text { Finalização da correção final e envio para os alunos, com orientação de envio a revistas científicas pelos } \\
\text { próprios alunos }{ }^{11}\end{array}$ \\
\hline 8 & Aplicação dos questionários (30 respostas) \\
\hline
\end{tabular}

Fonte: elaborado pelas autoras

7 Em Garcia-Reis e Magalhăes (2016), apresentamos uma outra experiência, com alunos de Letras/ Português da mesma universidade, abordando a sequência didática realizada com o artigo científico, logo após a realizaçáo desta pesquisa e a constataçáo de que a escrita de relatos de experiência e artigo científico havia sido bem sucedida em turmas anteriores.

8 Usamos, por exemplo, artigos da Revista Metodologia do Ensino de Língua Portuguesa - MELP (USP)

9 Tal procedimento foi realizado com base no modelo didático de gênero (MDG) da perspectiva teórica do ISD, que nâo vamos detalhar aqui por năo se tratar do objetivo do artigo. Basicamente, o artigo deveria conter as seçóes seguintes: introduçáo, fundamentaçáo teórica, descriçáo de um conjunto de 4 a 8 aulas das observadas, análise das aulas, consideraçóes finais, referências e anexos.

10 As seçôes do relato foram oriundas das leituras realizadas de outros relatos, de forma que deveriam conter: introduçăo, caracterizaçăo da escola e da turma, fundamentaçăo teórica, descriçăo da experiência, avaliaçâo dos resultados e consideraçóes finais.

11 Năo houve, de nossa parte, um controle sobre o envio dos artigos para revistas científicas, uma vez que finalizamos o período após a entrega dos questionários. Numa experiência posterior, realizamos esse controle organizando um volume especial de revista destinada a alunos de graduaçâo (GARCIA-REIS e MAGALHÁES, 2016). 
Durante o encaminhamento desta sequência de atividades, as aulas foram bastante reflexivas, dialogadas, de modo que pudéssemos interagir ao máximo sobre a prática social que o gênero é, sobre a observaçâo e a docência no estágio realizado, sobre a circulaçấo dos textos acadêmicos e a geraçăo de conhecimento no lócus escolar, bem como a importância de produzir conhecimento novo a partir das experiências travadas nos estágios na formaçấo inicial e a importância de tal conhecimento ser disseminado para além das reflexōes realizadas na universidade. Podemos ressaltar que as aulas foram extremamente ricas em discussâo, negociaçăo de sentidos e dúvidas.

Passamos, em seguida, a apresentar os dados relativos aos questionários.

\section{A ESCRITA DO ARTIGO E DO RELATO NO CURSO DE LETRAS}

Para podermos analisar a compreensăo que os alunos tiveram da escrita dos gêneros em questâo, bem como suas dúvidas, dividimos esta seçâo em duas partes para organizar melhor os dados, que foram analisados e apresentados abaixo em partes relativas às questóes respondidas. Em algumas, apresentamos quadros e gráficos apenas para visualizar melhor as respostas, mas năo pretendemos, com isso, propor uma análise quantitativa.

\section{Questăo 1 - A escrita de artigo e relato de experiência}

A primeira questăo do instrumento de coleta dos dados era fechada, com resposta sim ou năo. A pergunta questionava se o aluno já havia escrito artigo científico ou relato de experiência em alguma disciplina. $80 \%$ dos alunos nunca haviam escrito um artigo. Os outros $20 \%$ afirmaram ter escrito em atividades de iniciaçăo científica e outras disciplinas. Em relaçăo ao relato de experiência, 100\% nunca havia escrito um. Acreditamos que isso se deve à falta de oportunidades de prática pedagógica ao longo do curso, ainda que hoje tenhamos o Programa Institucional de Bolsa de Iniciaçăo à Docência (PIBID) em nossa universidade, e que haja projetos de extensăo e treinamento profissional, com possível atuaçáo em escolas. Embora saibamos que muitos alunos das licenciaturas já lecionam nesses projetos e também já atuam como docentes, nâo parece que a escrita de relatos de experiência seja uma prática frequente neste curso.

Antes de responder aos questionários, no decorrer do período, já havíamos perguntado aos alunos sobre a disciplina de Práticas de Gêneros Acadêmicos, ofertada como obrigatória no $1^{\circ}$ período do curso de Letras, na expectativa de que eles já haviam lido e escrito os gêneros acadêmicos enfocados em nossas disciplinas, de modo que teríamos que refletir sobre aspectos discursivos relativos à circulaçăo, seçóes já abordados. Entretanto, os discentes afirmaram que a disciplina enfocou, naquela turma, leitura de artigos científicos, escrita de resenha acadêmica, bem como orientaçōes sobre sintaxe e outras dificuldades trazidas pelos alunos (como pontuaçâo, articulaçăo de parágrafos etc.). Foi justamente por essa razăo que nos reorganizamos e realizamos as atividades de análise dos artigos, de 1 a 7 já apresentadas no quadro 3 anteriormente. Ficamos bastante surpresas ao constatar que $80 \%$ nunca havia escrito um artigo, uma vez que os alunos estavam no final do curso e uma vez que no meio acadêmico esse é um gênero muito comum. Acreditamos que a escrita do artigo traz desenvolvimento para os alunos no aprendizado da sistematizaçâo de conhecimento 
para elaboraçăo de fundamentaçâo teórica, conforme já dissemos, aspectos sobre metodologia e análise de dados, os quais saem das ricas cenas da sala de aula do estágio, de forma bastante aprofundada quanto à teoria discutida no curso. Além disso, possibilita uma consistente reflexăo sobre a relaçăo fundamentaçăo e análise, o que se desdobrou, no nosso caso, na relaçâo teoria e prática, gerando dificuldades, que passamos a discutir a seguir.

\section{Questăo 2: Dificuldades encontradas na escrita dos gêneros artigo e relato}

Em relaçăo à segunda questăo, que era "aberta" para livre resposta, perguntamos se os alunos tiveram dificuldades ao longo da elaboraçáo de seus textos. Dos 30 questionários analisados, 28 afirmaram apresentar dificuldades e 2 năo. Nesse item, apresentamos um trecho bastante interessante sobre esse tópico (Q - questionário):

"Tive dificuldade porque apesar do gênero artigo compor boa parte da bibliografia das disciplinas do curso de Letras, nunca nos foi requerida a produçăo de um." (Q10, q.2)

Percebemos que os alunos estăo, sim, interagindo com gêneros acadêmicos no curso, entretanto, pelo dado da aluna, o que confirma os dados da questăo 1, a escrita năo é trabalhada de forma sistematizada, sequer é requerida, a năo ser em atividades de Iniciaçăo Científica. Assim, a ideia de que basta ler o texto para produzi-lo vem à tona para a aluna nos últimos períodos do curso, reflexăo essa que se torna bastante positiva, se ela levar em conta tal fato também na sua prática futura de professora na Educaçăo Básica.

Das dificuldades encontradas, organizamos os dados abaixo em porcentagens para facilitar a visualizaçấo: ${ }^{12}$

Quadro 4: Dificuldades encontradas na escrita do artigo e do relato

\begin{tabular}{|c|c|}
\hline $\begin{array}{c}\text { Compreender as seções internas do artigo, articular as seções, encadear ideias, selecionar informações } \\
\text { para a seção teórica }\end{array}$ & $35,7 \%$ \\
\hline Usar formatação e normas da ABNT & $21,4 \%$ \\
\hline Utilizar vocabulário acadêmico/ escrita formal & $14,3 \%$ \\
\hline Fazer fundamentação teórica e citações & $10,7 \%$ \\
\hline Adequar tema à quantidade de páginas & $10,7 \%$ \\
\hline Analisar os dados e relacionar a teoria à prática & $7,2 \%$ \\
\hline Não especifica a dificuldade encontrada & $7,2 \%$ \\
\hline Afastar-se da própria prática para escrever sobre ela & $3,6 \%$ \\
\hline Diferenciar relato do artigo & $3,6 \%$ \\
\hline
\end{tabular}

Fonte: as autoras a partir de dados dos questionários

Vemos, entăo, pelos dados acima, que as questôes relativas às seçóes internas, à articulaçấo entre partes do texto, bem como às normas da ABNT e ao vocabulário săo bastante evidenciadas pelos discentes. Tais dúvidas a nosso ver revelam a falta de prática dos alunos na escrita acadêmica ao longo de sua graduaçăo, ainda que lidem com tais textos na leitura.

12 As porcentagens apresentadas sâo relativas à escrita do artigo e do relato conjuntamente, sendo que alguns discentes discorreram sobre um e/ou outro gênero, motivo pelo qual a contagem ultrapassa $100 \%$. 
Ainda sobre isso, apesar de elencar as dificuldades, os alunos informaram que as orientaçóes individuais foram fundamentais para vencer os obstáculos no momento da reescrita. Embora tenham percebido desafios, buscaram transpô-los conseguindo orientaçóes com colegas, leituras extras e orientaçóes com os professores das disciplinas, conforme veremos nas outras questóes.

\section{Questóes 3 e 4: contribuiçáo da escrita para a formaçăo e para a prática pedagógica e maior cuidado com a possibilidade de publicaçăo posterior}

A escrita do artigo e do relato, segundo os alunos, contribuiu sobretudo para conhecer os gêneros como forma de aprendizado para sua formaçâo acadêmica. É certo que muitos alunos, ao final da licenciatura, encaminham-se para programas de pós-graduaçăo, como ocorre na realidade da UFJF, em que publicaçôes săo altamente requeridas. Assim, deduzimos que tal formaçâo colabora também para a continuidade dos estudos em nível de pós-graduaçăo. Vejamos o gráfico abaixo relativo a esta questâo.

Gráfico 1: contribuições da escrita do artigo e do relato para a formação do aluno

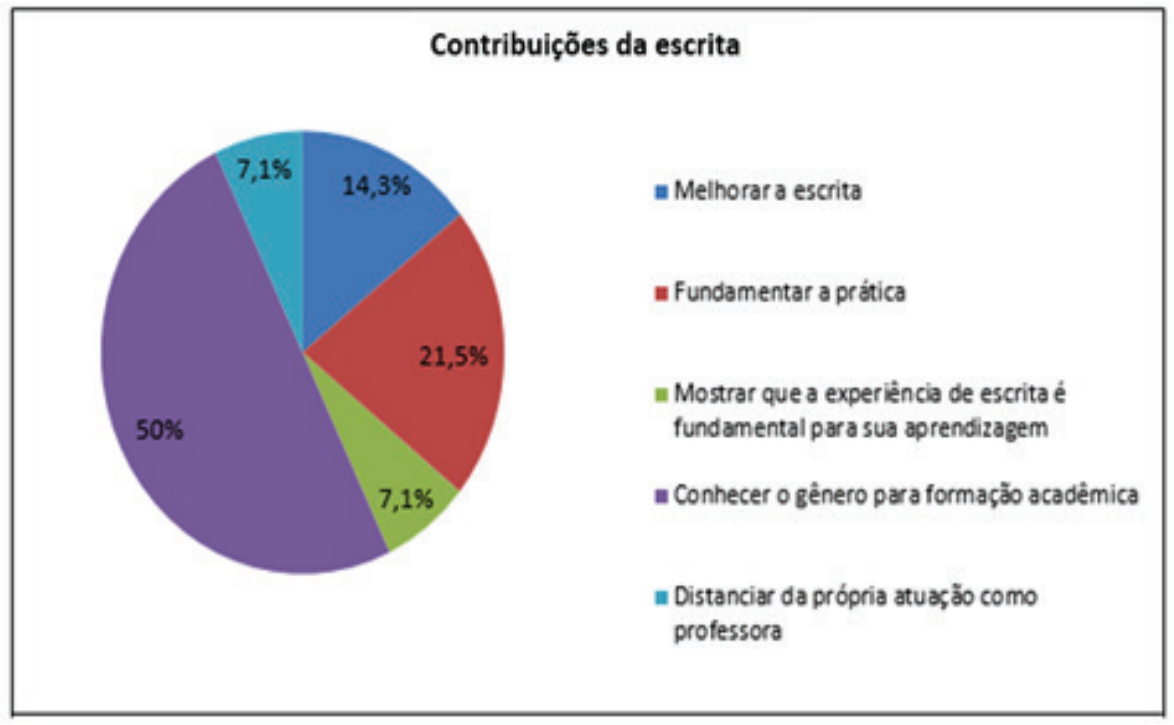

Fonte: Elaborado pelas autoras

Ressaltamos a oportunidade de distanciamento da própria prática que a escrita do relato proporcionou. Constatar que os alunos perceberam a relevância de escrever os gêneros, para além de lê-los, descrevê-los ou teorizar sobre eles, bem como reconheceram a reescrita como essencial para enxergar e superar as próprias dificuldades foi bastante significativo para nós, professoras do estágio. Os comentários abaixo reforçam isso:

Q 4 - "A escrita dos gêneros contribuiu para mostrar que é somente fazendo que aprendemos"

Q 15 - "Gostaria de ressaltar a importância da oportunidade de reescrita e também das observaçōes anotadas ao lado de nossos erros, pois às vezes náo enxergamos nosso erros" 
Por fim, dois alunos responderam que, embora artigo e relato tenham contribuído com a escrita acadêmica, o plano de intervençáo, que realizam antes de iniciar a docência, foi mais relevante do que a escrita desses dois gêneros. Essa resposta chamou-nos atençâo para um fato: sâo poucas as oportunidades, na graduaçăo em Letras da UFJF, de elaboraçăo de planos de trabalho, projetos de intervençăo ou até mesmo o tradicional plano de aula. Em menor quantidade ainda săo as oportunidades de elaborar materiais para a prática pedagógica, já que o livro didático é muito presente nas escolas. $\mathrm{Na}$ elaboraçăo desses materiais, podemos refletir sobre os conhecimentos adquiridos no curso, como as finalidades do ensino de Língua Portuguesa, os objetivos a serem alcançados, bem como os passos para alcançá-los. Essas reflexóes sâo essenciais para formar um professor autônomo.

Em relaçâo à questăo sobre a escrita e sua circulaçâo em revistas (questâo 4), a maioria respondeu que tal possibilidade influenciou sim em seu trabalho.

Gráfico 2: influência da possibilidade de publicação do texto na escrita dos trabalhos

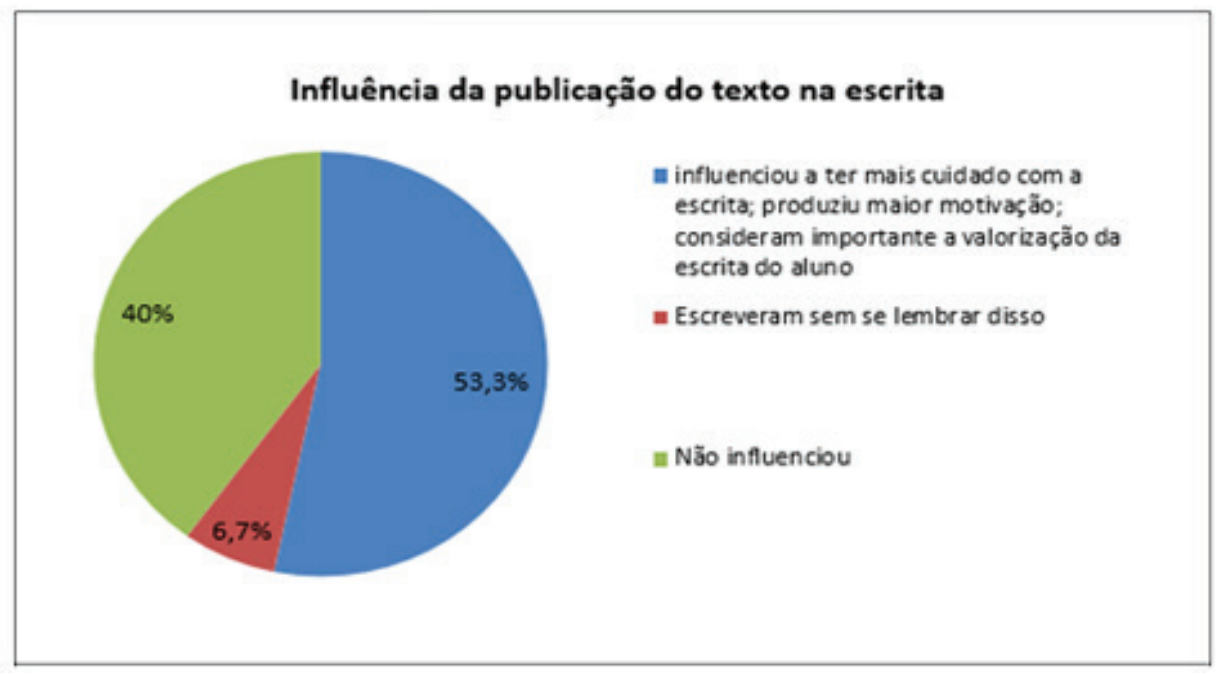

Fonte: Elaborado pelas autoras

A motivaçăo para a escrita é fundamental para năo cairmos no erro de apenas propor um exercício que seja apenas pretexto para a aprendizagem do gênero. Em nossas aulas na graduaçăo, enfatizamos tanto que na educaçấo básica a escrita dos discentes precisa circular para o aluno ser sujeito de seu próprio discurso e para que o ensino de linguagem faça mais sentido, mas muitas vezes năo exercitamos tal circulaçâo nos nossos cursos de licenciatura. A perspectiva que náo faz circular a açăo de linguagem pode induzir os alunos a usar o gênero como conteúdo desvinculado da prática social e da vida. Com a possibilidade de publicaçâo dos textos, os alunos sentem-se mais motivados, uma vez que se tornam verdadeiros autores de seus discursos reconhecidos pela comunidade leitora. Reforçamos a premissa de que a linguagem é social, e que colocar os alunos em situaçóes para agir pela linguagem, interagindo com outros membros da sociedade por meio dos resultados de seu estágio, significa reafirmá-los como seres sociais, autores, e năo reprodutores de um discurso. 


\section{Questăo 5: As estratégias utilizadas na escrita do artigo em funçăo de seu desconhecimento}

A última questăo proposta tematizou sobre as estratégias usadas para sanar as dúvidas em relaçăo aos gêneros que deveriam escrever ao longo do período, já que, como dissemos, realizamos pesquisas para tentar melhorar nossa prática como professoras, ampliando as possibilidades e táticas usadas em sala de aula para aprimorar ainda mais a formaçâo inicial. Assim, as respostas foram as seguintes:

\section{Gráfico 3 - Estratégias para superar dificuldades/dúvidas}

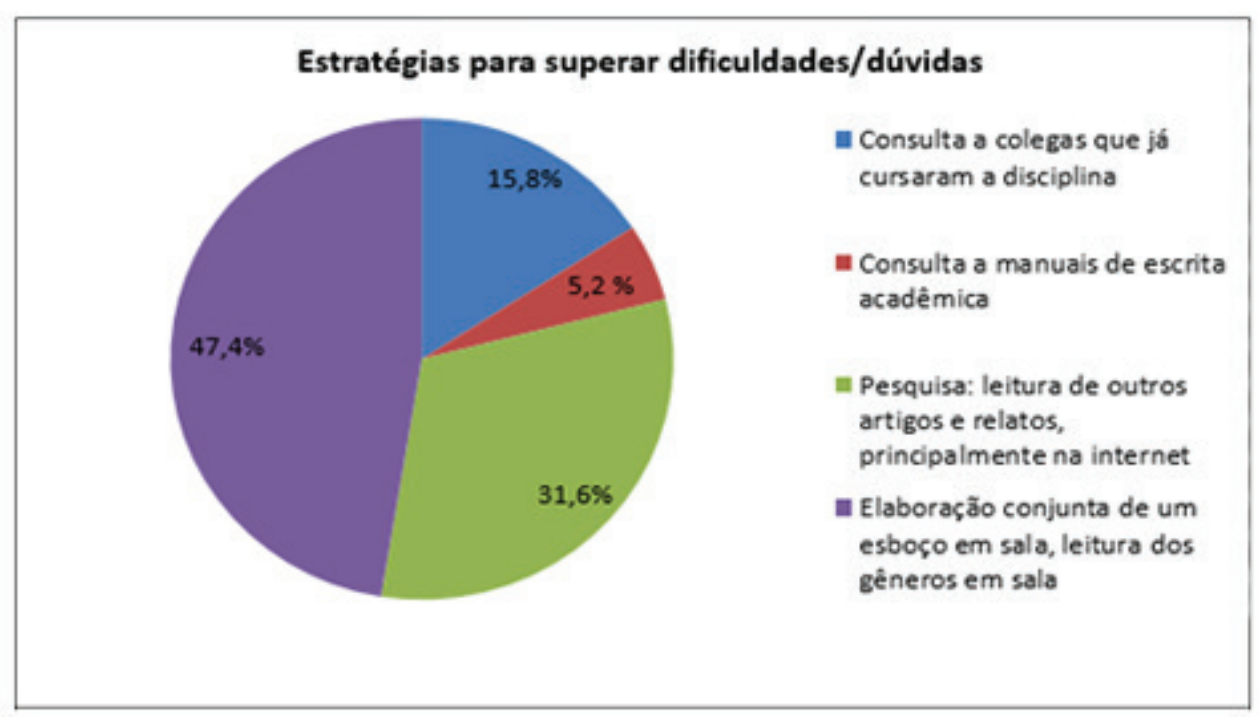

Fonte: Elaborado pelas autoras

Vemos pelos dados acima que a nossa mediaçâo em sala de aula, realizando leituras para reconhecimento dos gêneros, discutindo seu contexto de circulaçáo, seus interlocutores, bem como seu conteúdo temático e estilo foi fundamental para os alunos se tornarem autores de seu discurso, refletindo nos textos sobre sua atuaçấo no estágio. A construçăo conjunta de um plano geral do texto13 em sala, após a leitura de vários artigos, discussâo e negociaçáo com os alunos sobre quais poderiam ser tais seçóes internas em funçáo náo de um modelo pronto, mas da prática naquele estágio, foi primordial para o envolvimento e para a escrita final com êxito.

\section{OBSERVAÇÓES-SÍNTESE SOBRE OS DADOS}

Nosso objetivo, com essa pesquisa, era analisar as dificuldades e a compreensăo dos alunos sobre a escrita de artigo e relato nas disciplinas de RAEE I e II e Estágios. Consideramos muito positivas as reflexóes feitas por eles, o que nos conduziu a outros trabalhos de pesquisa nos períodos seguintes com as turmas subsequentes. Apesar de estarem no $7^{\circ}$ e $8^{\circ}$ períodos, a quase totalidade de alunos relatou ter

13 O plano geral dos textos está descrito nas notas 9 e 10. 
contato com a escrita do texto apenas nessa disciplina, com exceçâo dos que participam de atividades de iniciaçăo científica, que nâo se caracteriza como disciplina.

É preciso questionar se a aprendizagem de um gênero acadêmico como o artigo e o relato de experiência é "necessária" para a prática pedagógica em sala de ensino básico. Como năo săo gêneros que provavelmente vâo ser usados no cotidiano escolar com alunos de Ensino Fundamental e Médio, mas sim na prática de escrita profissional, entendemos que a importância da escrita na universidade se dá na experiência de se tornar autor, de visualizar a própria escrita e refletir sobre esse processo. Houve uma oportunidade de percepçâo das próprias dificuldades, infelizmente ao final do curso. Ainda sobre os dados dos questionários, uma aluna afirmou que a escrita do artigo serviu para ela verificar que estava se formando com muitos problemas de escrita, conforme podemos atestar neste excerto: "Mostrou que saio da faculdade com problemas na escrita, como pontuaçâo, acentuaçâo entre outros." Consideramos essa resposta bastante grave. Mais grave ainda é supor que năo é apenas uma aluna que assim se forma, mas vários alunos. Nesse sentido, nossas conclusôes nos levarâo a futuras açôes na formaçăo inicial no curso de Letras, sobretudo no que se refere aos estágios, mas năo desconectadas das outras disciplinas e atividades.

A escrita do relato permitiu um afastamento, um distanciamento da própria açâo pedagógica discente, fomentando interpretaçóes críticas sobre o próprio fazer docente, o que nos indica que o relato de experiência como um texto para a avaliaçáo final de sua própria intervençâo é válido e aprovado pelos alunos, além do relatório, como tradicionalmente é feito. Trazemos, para reforçar essa ideia, novamente as palavras de Andrade (2011) de que a escrita deve se constituir como um "procedimento formador [...]. A defesa é que escrever coloca o sujeito diante de sua própria história, ou de uma apresentaçáo particular única dessa história, pois é feita por quem a viveu" (SOUZA, 2006; LACERDA, 2010, apud Andrade, 2011).

Os discentes pouco escrevem textos acadêmicos com circulaçăo durante o curso, e quando escrevem, năo parecem ter retorno sobre sua escrita; por isso, náo percebem, ao longo de sua trajetória, suas próprias dificuldades, sentindo-se, como consequência, inseguros para a docência justamente naquilo que lhes falta, como professores de Língua Portuguesa. Nossas investigaçóes agora devem nos guiar para analisar se as provas e os "trabalhos" ainda estăo fortemente presentes nas disciplinas de formaçấo inicial nas licenciaturas, em vez de textos que circulam socialmente para além das disciplinas.

Também se mostrou fundamental uma mediaçăo, que incidiu diretamente na orientaçâo sobre a escrita e na indicaçâo dos problemas encontrados nos textos dos alunos, somados à reescrita, constituindo-se, para vários deles, uma grande oportunidade de aprendizagem ao longo da disciplina.

A possibilidade de circulaçâo do texto influenciou no trabalho de escrita, possibilitando oportunidade de autoria, o que é um bom indício de que nossas atividades de produçăo de texto, com vistas à apropriaçăo do conhecimento, devem ser cada vez mais desenvolvidas na formaçăo inicial com publicaçóes discentes. Reafirmamos, assim, que essa formaçăo discursiva de professores, conforme apresentamos, deve estar no centro de nossas atividades, pautando-nos em situaçôes práticas que 
dialoguem e coloquem os estudantes em contato mais intenso com a teoria. Nesse sentido, é necessário criar espaços e situaçôes para fazer circular o discurso escrito do professor em formaçâo.

\section{CONSIDERAÇÕES FINAIS}

As pesquisas que vimos realizando têm nos trazido algumas constataçôes bastante proveitosas para construir novas histórias de formaçăo inicial docente. Vimos a importância do trabalho de escrita nas disciplinas perpassando a relaçăo teoria-prática, com o intuito de formar professores para atuaçăo como profissionais qualificados para o ensino de Língua Portuguesa na educaçăo básica. Nessa pesquisa, ficou claro que devemos persistir na formaçăo do professor enfatizando e investindo na ampliaçăo de sua própria competência de escrita.

Este é um ponto em que a relaçăo teoria-prática se torna uma "unidade teoria-prática": a formaçăo dos professores de Língua Portuguesa deve ser discursiva, ou seja, fazer os alunos interagirem por meio de textos com sua comunidade, para que, na prática pedagógica futura, lidem melhor com seu objeto de trabalho, as açōes de linguagem, os gêneros materializados em textos. A compreensăo dessa perspectiva torna-se năo apenas teórica, mas vivenciada, experimentada, reforçada pelo papel que o aluno assume de sujeito-autor.

Assim, dessa etapa, encaminhamo-nos para outros questionamentos, que estăo agora como novos desafios ${ }^{14} \mathrm{em}$ andamento: quais sáo as práticas de escrita que os alunos exercem nas demais disciplinas do curso? De que modo as Diretrizes Curriculares Nacionais para a formaçâo de professores orientam esse processo? Há exercícios de escrita na perspectiva interdisciplinar? Com que finalidade os alunos escrevem textos nas diferentes disciplinas da nossa licenciatura Letras - Português?

As futuras respostas poderăo conferir um caráter mais preciso das práticas de escrita de nossos alunos para, entấo, repensarmos os eixos da formaçăo docente, com vistas a alcançar um exercício profissional mais embasado e profícuo.

14 Referimo-nos à pesquisa da $2^{\mathrm{a}}$ autora deste artigo, financiada pela UFJF, atualmente em desenvolvimento: "Formaçăo de professores e Ensino de Língua Portuguesa: reflexóes sobre a prática da linguagem por meio dos gêneros textuais". 


\section{REFERÊNCIAS}

ANDRADE, L. T. Uma proposta discursiva de formaçấo docente. Revista Práticas de Linguagem. v. 1, n. 2, jul./dez. 2011. Disponível em http://www.uff.br/praticasdelinguagem/files/2012/02/Fale-para-o-professor-Uma-proposta-discursiva-deforma\%C3\%A7\%C3\%A3o-docente-C\%C3\%B3pia.pdf Acesso em: jan. 2016.

BAGNO, M. Língua, linguagem, linguística: pondo os pingos nos is. Săo Paulo: Parábola Editorial, 2014.

BEZERRA, B. G. Letramentos acadêmicos na perspectiva dos gêneros textuais. Fórum Linguístico, Florianópolis, v. 9, n. 4, pp. 247-258, out./dez. 2012. Acesso em: abril 2014. Disponível em: https://periodicos.ufsc.br/index.php/forum/article/ view/1984-8412.2012v9n4p247/24296

BRASIL/MEC. Secretaria de Educaçâo Fundamental. Parâmetros curriculares nacionais: primeiro e segundo ciclos do ensino fundamental. Língua Portuguesa / Brasília: MEC/SEF, 1997.

Secretaria de Educaçăo Fundamental. Parâmetros curriculares nacionais: terceiro e quarto ciclos do ensino fundamental: Língua Portuguesa. Brasília: MEC/SEF, 1998.

BRONCKART, J. P. Atividades de linguagem, discurso e desenvlvimento humano. (organizaçăo Anna Rachel Machado; Maria de Lourdes Meirelles Matencio; traduçâo Anna Rachel Machado; Maria de Lourdes Meirelles Matencio (et al). Campinas-SP: Mercado de Letras, 2006.

Gêneros de textos, tipos de discurso e sequências. Por uma renovaçâo no ensino da produçăo escrita. Revista Letras. Santa Maria, v. 20, n. 40, pp. 163-176, 2010

Meio século de didática da escrita nos países francófonos: balanço e perspectivas. In: RINCK, F.; BOCH. F.; ASSIS, J.A. Letramento e formaçâo universitária: formar para a escrita e pela escrita. Campinas- SP: Mercado de Letras, 2015.

CRISTÓVÂO, V.L.L; BORK, A. V. B.; VIEIRA, I. R. Mapeamento de grupos de pesquisa em torno de letramento (em língua materna): desdobramentos do Projeto ILEES no Brasil. LETRAS \& LETRAS , v. 31, n. 3. jul./dez, 2015 Acesso em janeiro de 2016. Disponível em: http://www.seer.ufu.br/index.php/letraseletras/article/view/30593/16707

FERRAREZI Jr., C. Pedagogia do silenciamento. Săo Paulo: Parábola, 2014

FIAD, R. S; SILVA, L. L. M. Escrita na formaçăo docente: relatos de estágio. Acta Scientiarum. Maringá, v. 31, n. 2, pp. 123-131, 2009 Acesso em janeiro de 2016.

Disponível em http://eduem.uem.br/ojs/index.php/ActaSciLangCult/article/view/3600 GARCIA-REIS, A. R.; MAGALHÂES, T. G. As experiências de escrita na formaçăo de professores de Língua Portuguesa: uma prática no curso de Letras da UFJF. In: GARCIAREIS, A. R.; MAGALHĂES, T. G. Letramentos e práticas de ensino. Campinas, SP: Editora Pontes, 2016.

GATTI, B. A. Formaçăo de professores no Brasil: características e problemas. Educaçăo e Sociedade. Campinas, v. 31, n. 113, pp. 1355-1379, out.-dez. 2010. 
MARINHO, M. A escrita nas práticas de letramento acadêmico. Revista Brasileira de Linguística Aplicada, v. 10, n. 2, pp. 363-386, 2010.

MENDES, A. S.; SILVA, W. R.; GONÇALVES, A. V.; MELO, L. C. Intensificaçâo da reflexâo na escrita do professor em formaçâo inicial: uma abordagem sistêmico-funcional. Revista Filologia e Linguística, Săo Paulo, v. 17, n. 2, pp. 509-537, jul./dez. 2015. Acesso em julho de 2016

Disponível em http://revistas.usp.br/flp/article/view/95938/111829

MOTTA-ROTH, D.; HENDGES, G. R. Produçáo textual na universidade. Săo Paulo: Parábola editorial, 2010.

RINCK, F.; BOCH. F.; ASSIS, J.A. Apresentaçăo. In: Letramento e formaçăo universitária: formar para a escrita e pela escrita. Campinas-SP: Mercado de Letras, 2015.

STREET, B. Academic Literacies approaches to Genre? Revista Brasileira de Linguística Aplicada, Belo Horizonte, v. 10, n. 2, pp. 347-361, 2010. 